\title{
Supplementation With Purple Corn Anthocyanin Improves Growth Performance, Meat Quality, Muscle Antioxidant Status and Unsaturated Fatty Acid Profiles in Growing Goat
}

\section{Research}

Keywords:

Posted Date: April 27th, 2021

DOI: https://doi.org/10.21203/rs.3.rs-359148/v2

License: (1) This work is licensed under a Creative Commons Attribution 4.0 International License. Read Full License 


\section{Abstract}

The authors have requested that this preprint be withdrawn due to author disagreement.

\section{Full Text}

The authors have withdrawn this preprint from Research Square. 